\title{
PEMILU SERENTAK (PEMILU LEGISLATIF DENGAN PEMILU PRESIDEN DAN WAKIL PRESIDEN) DAN PENGUATAN SISTEM PRESIDENSIAL
}

(The Simultaneous of election (Legislative Election, President and Vice President's election) and Strengthening of the Presidential System)

\author{
Sodikin \\ Fakultas Hukum Universitas Muhammadiyah Jakarta \\ Jl. KH Ahmad Dahlan Ciputat Jakarta Selatan \\ Email: sodikin68@gmail.com
}

Naskah diterima: 17 Maret 2014; revisi: 11 April 2014; disetujui: 29 April 2014

\begin{abstract}
Abstrak
Permasalahan ini dilatarbelakangi adanya putusan Mahkamah Konstitusi yang dalam putusannya memutuskan uji materi norma Pasal 3 ayat (4), Pasal 9, Pasal 14 ayat (2) dan Pasal 112 Undang-Undang Nomor 42 Tahun 2008 tentang Pemilihan Presiden dan Wakil Presiden terhadap UUD 1945. Mahkamah Konstitusi memutuskan bahwa pasal-pasal tersebut, kecuali Pasal 9 Undang-Undang Nomor 42 Tahun 2008 tidak mempunyai kekuatan mengikat, sehingga pemilu dapat dilaksanakan secara bersamaan atau serentak antara pemilu Presiden dan Wakil Presiden dengan pemilu legislatif tahun 2019. Terjadinya polemik atas putusan Mahkamah Konstitusi tersebut, karena pemilu serentak dapat dilaksanakan pada 2019, bukannya dilaksanakan pada 2014 sekarang ini. Selain itu, Mahkamah Konstitusi tidak mempermasalahkan ambang batas (presidential threshold) yang terdapat dalam Pasal 9 Undang-Undang Nomor 42 Tahun 2008, karena masalah tersebut dikembalikan kepada pembentuk Undang-Undang. Permasalahannya dalam tulisan ini adalah apakah pemilu serentak pada 2019 dapat meniadakan atau masih mempergunakan ambang batas (presidential threshold) dalam pemilu presiden dan wakil presiden. Ada perbedaan pendapat terhadap ambang batas (presidential threshold) karena akan mempengaruhi penguatan sistem presidensial yang dianut dalam UUD 1945. UUD 1945 menganut sistem presidensial murni yang mempunyai kedudukan yang kuat, sehingga presiden dalam menjalankan pemerintahannya mempunyai posisi yang kuat, meskipun tidak didukung oleh mayoritas parlemen, karena presiden tidak bertanggung jawab kepada parlemen, tetapi bertanggung jawab kepada rakyat yang memilihnya.
\end{abstract}

Kata Kunci: Pemilu, Sistem Presidensial, Ambang Batas

\begin{abstract}
This problem is motivated from the Constitutional Court's verdict that decide to judicial review norms of Article 3 verse (4), Article 9, Article 14 verse (2) and Article 112 of Law Number 42 Year 2008 on the Election of President and VicePresident under the Republic of Indonesia's 1945 Constitution. The Constitutional Court decided all that articles except article 9 in Law Number 42 Year 2008 did not have legal bonding to make the President and Vice President's election run alongside the legislative's election in 2019. Problems comes because the President and Vice President's election run alongside the legislative's election will run in 2019 not in this 2014's election. Besides, The Constitutional Court did not matters the presidential threshold contained in Article 9 of Law No. Number 42 Year 2008, because that matter returned to the legislators. The problem in this paper is whether simultaneous election in 2019 may negate or still using presidential threshold election for president and vice president. There are different opinions on the presidential threshold because it will affect the strengthening of the presidential system adopted in the Republic of Indonesia's 1945 Constitution. the Republic of Indonesia's 1945 Constitution adheres pure presidential system that has a strong position, so the president in running his government has a strong position, even though not supported by a majority of the parliament, because the president is not responsible to parliament, but responsible to the people who choose him.
\end{abstract}

Keywords: Election, Presidential System, Presidential Threshold 


\section{A. Pendahuluan}

Pemerintahan sistem presidensial adalah suatu sistem pemerintahan di mana kedudukan eksekutiftidak bertanggung jawab kepada badan perwakilan rakyat, dengan kata lain kekuasaan eksekutif berada di luar pengawasan (langsung) parlemen. ${ }^{1}$ Dalam tipe ini kedudukan eksekutif tidak tergantung kepada badan perwakilan rakyat, adapun dasar hukum kekuasaan eksekutif dikembalikan kepada pemilihan rakyat. ${ }^{2}$ Oleh karena itu, melalui amandemen UUD 1945, kepala negara dan kepala pemerintahannya adalah seorang Presiden, dan Presiden beserta wakilnya dipilih langsung oleh rakyat. Pemilihan dilakukan secara demokratis, Pasal 7 UUD 1945 menyatakan bahwa: "Presiden dan Wakil Presiden memegang jabatan selama lima tahun dan sesudahnya dapat dipilih kembali dalam jabatan yang sama, hanya untuk satu kali masa jabatan". Pergantian Presiden merupakan sebuah proses yang umum terjadi di setiap negara, yang menerapkan sistem republik. Proses ini menunjukkan suatu negara dari pemimpin yang terdahulu, atau juga merupakan proses kesadaran rakyat untuk memilih seseorang atau partai yang dianggap mampu menampung aspirasi mereka. ${ }^{3}$

Dalam hal pengisian jabatan Presiden dan Wakil Presiden, UUD 1945 mengatur tata cara pemilihan Presiden dan Wakil Presiden, yaitu Pasal 6A ayat (5) UUD 1945 menyatakan: "Tata cara pelaksanaan pemilihan Presiden dan Wakil Presiden lebih lanjut diatur dalam undang- undang". Undang-Undang yang dimaksud untuk pemilu Presiden dan Wakil Presiden 2014 adalah Undang-Undang Nomor 42 Tahun 2008. Undang-Undang ini memberikan pengaturan teknis dalam pemilihan Presiden dan Wakil Presiden, agar pemilihan umum dapat dilaksanakan secara demokratis. Dalam perkembangan politik dan ketatanegaraan saat ini adalah mengenai mekanisme pemilihan Presiden dan Wakil Presiden yang dilaksanakan secara serentak dengan pemilu legislatif.

Pemilu serentak yaitu pelaksanaan pemilu legislatif dan pemilu Presiden dan Wakil Presiden dilaksanakan secara bersamaan. Perlunya pemilu serentak merupakan hasil uji materi Undang-Undang Nomor 42 Tahun 2008 terhadap UUD 1945 kepada Mahkamah Konstitusi. Selanjutnya Mahkamah Konstitusi dalam putusannya menyatakan bahwa penyelenggaraan pemilu legislatif dan pemilu Presiden dan Wakil Presiden dapat diselenggarakan secara bersamaan tahun 2019. Putusan ini menimbulkan pro kontra karena dapat diselenggarakan tahun 2019, sehingga apakah pemilu Presiden dan Wakil Presiden 2014 dapat dianggap konstitusional.

Sebenarnya tidak hanya konstitusional atau inkonstitusional pemilu Presiden dan Wakil Presiden yang diselenggarakan pada 2014, tetapi ada permasalahan yang berkaitan dengan sistem presidensiil di Indonesia ini. Pembentuk Undang-Undang pada saat membentuk Undang-Undang Nomor 42 Tahun 
2008 memberikan persyaratan bagi partai politik untuk mengusulkan pasangan calon. Hal ini, karena sistem presiden pada hakikatnya mempunyai filosofi yang berbeda dengan sistem parlementer. Dalam sistem presidensial, bahwa penekanan diletakkan pada Presiden sebagai lembaga eksekutif dengan lembaga legislatif sebagai pengontrol. Dengan demikian, pembentuk undang-undang memberikan syarat pengusulan Presiden yang diberi nama ambang batas (presidential threshold) bagi partai politik atau gabungan partai politik. Di sini menurut Harun Alrasyid, dalam suatu negara demokrasi, calon Presiden pada umumnya ditentukan melalui seleksi yang dilakukan oleh partai politik. ${ }^{4}$ Partai politik mempunyai peranan dalam proses demokrasi, sehingga UUD 1945 memberikan pengaturan dalam pengusulan calon Presiden dan Wakil Presiden yang dilakukan oleh partai politik.

\section{B. Permasalahan}

Permasalahan yang muncul adalah implikasi dari uji materi Pasal 3 ayat (5), Pasal 9, Pasal 12 ayat (1) dan (2), Pasal 14 ayat (2) dan Pasal 112 Undang-Undang Nomor 42 Tahun 2008 tentang Pemilihan Umum Presiden dan Wakil Presiden terhadap Pasal 4 ayat (1), Pasal 6A ayat (2), Pasal 7C, Pasal 22E ayat (1), (2) dan (3) UndangUndang Dasar Negara Republik Indonesia Tahun 1945. Mahkamah Konstitusi berpendapat bahwa pasal-pasal tersebut bertentangan dan tidak mempunyai kekuatan hukum mengikat, sehingga harus dibatalkan. Selanjutnya dalam putusannya Mahkamah Konstitusi pada intinya bahwa pelaksanaan pemilu Presiden dan Wakil
Presiden dapat dilakukan serentak dengan pemilu legislatif, meskipun diselenggarakan pada 2019, namun Mahkamah Konstitusi tidak mengabulkan uji materi Pasal 9 UndangUndang Nomor 42 Tahun 2008. Sedangkan Pasal 9 Undang-Undang Nomor 42 Tahun 2008 menyatakan bahwa: "Pasangan calon diusulkan oleh Partai Politik atau Gabungan Partai Politik peserta pemilu yang memenuhi persyaratan perolehan kursi paling sedikit 20\% (dua puluh persen) dari jumlah kursi DPR atau memperoleh $25 \%$ (dua puluh lima) persen dari suara sah nasional dalam pemilu anggota DPR, sebelum pelaksanaan pemilu Presiden dan Wakil Presiden". Hal inilah yang kemudian dikenal dengan ambang batas (presidential threshold) perolehan bagi partai politik atau gabungan partai politik dalam mengusung calon Presiden dan Wakil Presiden.

Oleh karena itu, apakah Pasal 9 UndangUndang Nomor 42 Tahun 2008 yang mengatur ambang batas (presidential threshold) masih diberlakukan untuk pemilu Presiden tahun 2019 atau dibuat undang-undang baru yang tidak memuat ambang batas (presidential threshold). Pada awalnya pemberlakukan ambang batas (presidential threshold) oleh pembentuk Undang-Undang adalah dalam rangka penguatan sistem presidensial. Apabila melihat kembali pada pemilu Presiden dan Wakil Presiden 2009 dengan menggunakan Undang-Undang Nomor 42 Tahun 2008 ini dengan pemberlakuan ambang batas (presidential threshold) kenyataannya Presiden dalam menjalankan pemerintahan berjalan sesuai dengan UUD 1945 yaitu lima tahun tanpa harus dijatuhkan oleh parlemen.

\footnotetext{
Harun Alrasyid, Pengisian Jabatan Presiden (Jakarta: Pustaka Utama Grafiti, 1999), hlm. 24.
} 


\section{Metode Penelitian}

Metode penelitian yang digunakan adalah deskriptif normatif, yaitu menjelaskan, menggambarkan dan menganalisis suatu peristiwa atau keadaan yang terjadi. Maksudnya menganalisis pelaksanaan pemilu legislatif dan pemilu Presiden dan Wakil Presiden secara serentak dengan fokus pembahasan pada pemberlakuan ambang batas (presidential threshold) pengusulan calon Presiden dan Wakil Presiden. Data yang yang diperoleh adalah data sekunder yang bersifat kualitatif, seperti buku dan artikel yang berkaitan dengan pemilu, Undang-Undang Pemilu serta putusan Mahkamah Konstitusi. Begitu juga analisis yang digunakan adalah analisis kualitatif.

\section{Pembahasan}

\section{Sistem Presidensial Menurut UUD 1945}

Sejak dulu selalu dikatakan bahwa UUD 1945 menganut sistem pemerintahan presidensial, sekurang-kurangnya sistem demikian itulah yang semula dibayangkan ideal oleh kalangan perancang Undang-Undang Dasar 1945. ${ }^{5}$ Akan tetapi, sistem presidensial yang dianut UUD 1945 sebelum amandemen adalah tidakmurni, karena Presiden dalam menjalankan pemerintahannya harus mempertanggungjawabkannya kepada MPR sebagai lembaga parlemen yang mempunyai kedudukan sebagai lembaga tertinggi negara. Oleh karena itu, menurut Jimly, MPR juga berwenang memberhentikan Presiden di tengah masa jabatannya karena tuduhan pelanggaran haluan negara, lagi pula pengertian haluan negara itu sendiri bersifat sangat luas yaitu dapat mencakup pengertian politik dan hukum sekaligus. ${ }^{6}$

UUD 1945 hasil amandemen telah menentukan bahwa sistem pemerintahan Indonesia merupakan sistem presidensial secara murni. Menurut Arend Lijphart, bahwa sistem presidensial ini memiliki kelebihankelebihan di antaranya: kelebihan pertama dari pemerintahan presidential, stabilitas eksekutif didasarkan pada masa jabatan Presiden. Kedua, dari pemerintahan presidential adalah bahwa pemilihan kepala pemerintahan oleh rakyat dapat dipandang lebih demokratis dari pemilihan tak langsung, formal atau informal dalam sistem parlementer. Ketiga dari pemerintahan presidential adalah bahwa pemisahan kekuasaan berarti pemerintahan yang dibatasi, perlindungan kebebasan individu atas tirani pemerintah. ${ }^{7}$

Menurut Sri Soemantri, bahwa ciri-ciri sistem pemerintahan presidensial dalam UUD 1945 pasca amandemen antara lain: pertama, Presiden dan Wakil Presiden dipilih dalam satu pasangan secara langsung oleh rakyat; kedua, Presiden tidak lagi bertanggung jawab kepada MPR, karena lembaga ini tidak lagi sebagai pelaksana kedaulatan rakyat. ${ }^{8}$ Arend Lijphart

Jimly Asshiddiqie, Hukum Tata Negara dan Pilar-Pilar Demokrasi (Jakarta: Sinar Grafika, 2011), hlm. 97.

Ibid., hlm. 98.

Arend Lilphart (Penyadur: Ibrahim dkk), Sistem Pemerintahan Parlementer dan Presidensial (Jakarta: Raja Grafindo Persada, 1995), hlm. 14-17.

Sri Soemantri, "Kekuasaan danSistem Pertanggungjawaban Presiden Pasca Perubahan UUD 1945", (Makalah disampaikan pada Seminar Sistem Pemerintahan Indonesia Pasca Amandemen UUD 1945 yang diselenggarakan oleh Depkumham bekerja sama dengan Fakultas Hukum Unair dan Kanwil Depkumham Provinsi Jawa Timur di Surabaya pada tanggal 9-10 Juni 2004), hlm. 4. 
sebagaimana dikutip Deny Indrayana juga menyatakan, memberikan sistem presidensial dalam tiga kategori yang spesifik: (1) eksekutif yang dijalankan oleh satu orang, bukan gabungan; (2) eksekutif yang dipilih langsung oleh rakyat; dan (3) masa jabatan tertentu yang tidak bisa dicabut atau dihapuskan oleh pemungutan suara di parlemen. ${ }^{9}$

Berdasarkan beberapa pendapat tersebut, maka UUD 1945 sebagaimana dijelaskan di atas menganut sistem presidensial murni. Hal ini dapat dilihat bahwa Presiden dan Wakil Presiden dipilih langsung oleh rakyat, yaitu Pasal 6A ayat (1) UUD 1945 yang menyatakan bahwa: "Presiden dan Wakil Presiden dipilih secara langsung dalam satu pasangan secara langsung oleh rakyat". Berarti Presiden tidak lagi bertanggung jawab kepada lembaga negara yang ada termasuk lembaga parlemen. Pasal 6A ayat (2) UUD 1945 menyatakan bahwa: "Pasangan calon Presiden dan Wakil Presiden diusulkan oleh partai politik atau gabungan partai politik peserta pemilihan umum sebelum pelaksanaan pemilihan umum". Pasal ini menunjukkan bahwa partai politiklah yang menyeleksi calon Presiden dan Wakil Presiden dan partai politik mempunyai peranan yang penting dalam proses demokrasi. Partai politik yang memperoleh suara mayoritas di parlemen atau menguasai parlemen tidak dapat menjatuhkan Presiden dan Wakil Presiden, meskipun partai politik tersebut mengusungnya.

Begitu juga dari aspek politik bahwa selama lima tahun jabatannya kedudukan Presiden tidak dapat diganggu gugat, inilah yang kemudian dikenal sistem pemerintahan yang lima tahunan yang dinamakan fixed executive. Ketentuan ini terdapat dalam Pasal 7 UUD 1945 menyatakan bahwa: "Presiden dan Wakil Presiden memegang jabatan selama lima tahun dan sesudahnya dapat dipilih kembali dalam jabatan yang sama, hanya untuk satu kali masa jabatan". Ini berarti dalam sistem presidensial bentuk pertanggungjawabannya tidak kepada lembaga negara lain, tetapipertanggungjawaban Presiden adalah kepada rakyat setelah masa jabatannya selesai. Dengan indikator apabila untuk masa jabatan kedua Presiden tersebut masih terpilih berarti pertanggungjawabannya diterima rakyat.

Apabila Presiden diberhentikan dalam masa jabatannya, maka ada mekanisme yang harus dilalui, sehingga Presiden atau Wakil Presiden tidak dapat diberhentikan seenaknya. Pemberhentian Presiden dan Wakil Presiden dalam masa jabatannya dikarenakan sebagaimana ditentukan dalam Pasal 7A UUD 1945 yang menyatakan: "Presiden dan Wakil Presiden dapat diberhentikan dalam masa jabatannya oleh Majelis Permusyawaratan Rakyat atas usul Dewan Perwakilan Rakyat baik apabila terbukti telah melakukan pelanggaran hukum berupa pengkhianatan terhadap negara, korupsi, penyuapan, tindak pidana berat lainnya, atau perbuatan tercela maupun apabila terbukti tidak lagi memenuhi syarat sebagai Presiden dan/atau Wakil Presiden". Begitu juga mekanisme pemberhentian Presiden dan Wakil Presiden menurut UUD 1945 yang begitu panjang, baik melalui mekanisme politik maupun hukum, inilah yang kemudian UUD 1945 mengakomodir yang kemudian diatur dalam Pasal 7B.

9 Deny Indrayana, Amandemen UUD 1945, antara Mitos dan Pembongkaran (Jakarta: Mizan Pustaka, 2008), hlm. 375 . 
Dengan demikian, Pasal 7B UUD 1945 memungkinkan pemberhentian Presiden dan Wakil Presiden dapat saja dilakukan apabila memenuhi sebagaimana yang ditentukan dalam Pasal 7A UUD 1945. Usulan pemberhentian Presiden dan Wakil Presiden dapat saja diajukan oleh DPR kepada MPR dengan terlebih dahulu mengajukan permintaan kepda Mahkamah Konstitusi untuk memeriksa, mengadili dan memutus pendapat DPR bahwa Presiden dan Wakil Presiden telah melakukan pelanggaran sebagaimana dituduhkan dalam Pasal 7A UUD 1945. Pengajuan permintaan DPR kepada MK hanya dapat dilakukan dengan dukungan sekurang-kurangnya $2 / 3$ dari jumlah anggota DPR yang hadir dalam sidang paripurna yang dihadiri oleh sekurang-kurangnya $2 / 3$ dari jumlah anggota DPR. MK wajib memeriksa, mengadili dan memutus dengan seadiladilnya terhadap pendapat DPR, dan apabila MK memutuskan bahwa Presiden dan Wakil Presiden terbukti melakukan sebagaimana dituduhkan dalam Pasal 7A UUD 1945, maka DPR menyelenggarakan sidang paripurna untuk meneruskan usul pemberhentian Presiden dan Wakil Presiden kepada MPR. MPR wajib menyelenggarakan sidang untuk memutuskan usul DPR. Keputusan MPR atas usul pemberhentian Presiden dan/atau Wakil Presiden harus diambil dalam rapat paripurna MPR yang dihadiri oleh sekurang-kurangnya $3 / 4$ dari jumlah anggota dan disetujui oleh sekurang-kurangnya $2 / 3$ dari jumlah yang hadir. Dengan demikian, dapat saja Presiden dan Wakil Presiden diberhentikan, tetapi pemberhentian Presiden dan Wakil Presiden tersebut melalui mekanisme politik dan hukum yang panjang, sehingga Presiden dan Wakil Presiden tidak dapat diberhentikan dengan alasan-alasan yang tidak konstitusional.
Selanjutnya dalam hal pengangkatan dan pemberhentian menteri-menteri, Presiden mempunyai kewenangan yang penuh untuk pengangkatan dan pemberhentian menterimenteri. Parlemen tidak dapat membubarkan atau memberhentikan para pembantu Presiden dalam hal ini adalah menteri-menteri. Ketentuan hal ini terdapat dalam Pasal 17 ayat (1) dan (2) yang menyatakan: ayat (1): Presiden dibantu oleh menteri-menteri negara, ayat (2): Menteri-menteri itu diangkat dan diberhentikan oleh Presiden. Dengan demikian, dalam konteks sistem pemerintahan presidensial, menteri-menteri diangkat dan diberhentikan oleh Priesiden karena ia bertanggung jawab kepada Presiden. Menteri-menteri adalah bukan pegawai tinggi biasa tetapi mempunyai kedudukan sebagai pemimpin kementerian di bidangnya. Dalam hal demikian, menterimenteri mempunyai pengaruh besar terhadap Presiden dalam menentukan politik negara yang mengenai bidang dalam kementeriannya.

Dengan demikian, UUD 1945 setelah amandemen ini menganut sistem presidensial murni, dan Presiden dan Wakil Presiden tidak dapat diberhentikan oleh lembaga negara manapun. Kedudukan Presiden sangat kuat tidak bisa dimakzulkan dengan alasan-alasan inkonstitusional. Lembaga parlemen yang memang berisi partai politik dalam UUD 1945 hanya mempunyai berfungsi legislasi, fungsi anggaran, dan fungsi pengawasan, dan tidak mempunyai fungsi pemakzulan.

\section{Implikasi Putusan Mahkamah Konstitusi}

Putusan Mahkamah Konstitusi Nomor 14/ PUU-XI/2013 menimbulkan polemik yang berkepanjangan. Putusan Mahkamah Konstitusi tersebut diajukan oleh pemohon untuk menguji 
Pasal 3 ayat (5), Pasal 9, Pasal 12 ayat (1) dan (2), Pasal 14 ayat (2) dan Pasal 112 UndangUndang Nomor 42 Tahun 2008 terhadap Pasal 4 ayat (1), Pasal 6A ayat (2), Pasal 22E ayat (1) dan ayat (2), Pasal 27 ayat (1), Pasal 28D ayat (1), Pasal $28 \mathrm{H}$ ayat (1), dan Pasal 33 ayat (4) UUD 1945. Mahkamah Konstitusi pada akhirnya memutuskan uji materi pasal-pasal tersebut dan tidak mengabulkan Pasal 9 Undang-Undang Nomor 42 Tahun 2008. Akan tetapi, putusan tersebut dapat dilaksanakan untuk pemilu Presiden dan Wakil Presiden tahun 2019 bukan untuk pemilu 2014. Putusan tersebut akhirnya menimbulkan pro kontra dengan polemik bahwa pemilu Presiden dan Wakil Presiden 2014 dianggap inskonstitusional.

Ada beberapa argumen yang dikemukakan Mahkamah Konstitusi dalam putusannya terhadap konstitusionalnya pemilu Presiden dan Wakil Presiden adalah konstitusional, di antaranya:

1. Bahwa tahapan penyelenggaraan pemilihan umum tahun 2014 telah dan sedang berjalan mendekati waktu pelaksanaan. Seluruh ketentuan peraturan perundang-undangan mengenai tata cara pelaksanaan pemilihan umum, baik Pilpres maupun Pemilu Anggota Lembaga Perwakilan, telah dibuat dan diimplementasikan sedemikian rupa. Demikian juga persiapan-persiapan teknis yang dilakukan oleh penyelenggara termasuk persiapan peserta pemilihan umum dan seluruh masyarakat Indonesia telah sampai pada tahap akhir, sehingga apabila Pasal 3 ayat (5) UU 42/2008 dan ketentuanketentuan lain yang berkaitan dengan tata cara dan persyaratan pelaksanaan Pilpres yang akan diputuskan dalam perkara ini harus diberlakukan segera setelah diucapkan dalam sidang terbuka untuk umum maka tahapan pemilihan umum tahun 2014 yang saat ini telah dan sedang berjalan menjadi terganggu atau terhambat, terutama karena kehilangan dasar hukum. Hal demikian dapat menyebabkan pelaksanaan pemilihan umum pada tahun 2014 mengalami kekacauan dan menimbulkan ketidakpastian hukum yang justru tidak dikehendaki karena bertentangan dengan UUD 1945;

2. Selain itu, dengan diputuskannya Pasal 3 ayat (5) UU 42/2008 dan ketentuanketentuanlain yang berkaitan dengan tata cara dan persyaratan pelaksanaan Pilpres maka diperlukan aturan baru sebagai dasar hukum untuk melaksanakan Pilpres dan Pemilu Anggota Lembaga Perwakilan secara serentak. Berdasarkan Pasal 22E ayat (6) UUD 1945, ketentuan lebih lanjut tentang pemilihan umum haruslah diatur dengan Undang-Undang. Jika aturan baru tersebut dipaksakan untuk dibuat dan diselesaikan demi menyelenggarakan Pilpres dan Pemilu Anggota Lembaga Perwakilan secara serentak pada tahun 2014, maka menurut penalaran yang wajar, jangka waktu yang tersisa tidak memungkinkan atau sekurang-kurangnya tidak cukup memadai untuk membentuk peraturan perundangundangan yang baik dan komprehensif;

3. Langkah membatasi akibat hukum yang timbul dari pernyataan inkonstitusionalitas atau bertentangan dengan UUD 1945 suatu Undang- Undang pernah dilakukan Mahkamah dalam Putusan Nomor 012-016019/PUU-IV/2006, bertanggal 19 Desember 2006. Menurut putusan Mahkamah tersebut, Pengadilan Tindak Pidana Korupsi (Tipikor) harus dibentuk dengan UndangUndang tersendiri, paling lambat tiga tahun sejak dikeluarkannya putusan MK tersebut; 
dan juga dalam Putusan Nomor 026/PUUIII/2005, bertanggal 22 Maret 2006 mengenai Pengujian Undang-Undang Nomor 13 Tahun 2005 tentang Anggaran Pendapatan Belanja Negara Tahun Anggaran 2006, yang hanya membatasi akibat hukum yang timbul dari putusan Mahkamah sepanjang menyangkut batas tertinggi Anggaran Pendidikan;

4. Merujuk pada Putusan Nomor 012-016019/PUU-IV/2006 dan Putusan Nomor 026/PUU-III/2005 tersebut, maka dalam perkara ini pembatasan akibat hukum hanya dapat dilakukan dengan menangguhkan pelaksanaan putusan a quo sedemikian rupa sampai telah terlaksananya Pilpres dan Pemilu Anggota Lembaga Perwakilan tahun 2014. Selanjutnya, penyelenggaraan Pilpres dan Pemilu Anggota Lembaga Perwakilan harus mendasarkan pada putusan Mahkamah a quo dan tidak dapat lagi diselenggarakan Pilpres dan Pemilu Anggota Lembaga Perwakilan secara terpisah. Selain itu, Mahkamah berpendapat memang diperlukan waktu untuk menyiapkan budaya hukum dan kesadaran politik yang baik bagi warga masyarakat, maupun bagi partai politik untuk mempersiapkan diri dan melaksanakan agenda penting ketatanegaraan;

5. Meskipun Mahkamah menjatuhkan putusan mengenai Pasal 3 ayat (5), Pasal 12 ayat (1) dan ayat (2), Pasal 14 ayat (2), dan Pasal 112 UU 42/2008, namun menurut Mahkamah penyelenggaraan Pilpres dan Pemilu Anggota Lembaga Perwakilan tahun 2009 dan 2014 yang diselenggarakan secara tidak serentak dengan segala akibat hukumnya harus tetap dinyatakan sah dan konstitusional. ${ }^{10}$

Mahkamah Konstitusi mengabulkan sebagian uji materi Undang-Undang Nomor 42 Tahun 2008, bahwa pemilu serentak dapat dilaksanakan pada 2019, sebab apabila dilaksanakan pada 2014 menurut Mahkamah, maka pelaksanaan pemilu dapat menimbulkan kekacauan dan menimbulkan ketidakpastian hukum. Putusan ini berimplikasi pada pemilu Presiden dan Wakil Presiden yang harus dilaksanakan secara serentak pada tahun 2019 dan apakah pemilu Presiden dan Wakil Presiden yang serentak dengan Pemilu legislatif masih memerlukan ambang batas (presidential threshold), karena pembentuk Undang-Undang Nomor 42 Tahun 2008 dengan alasan bahwa pemilu legislatif didahulukan daripada pemilu Presiden dan Wakil Presiden adalah untuk memperkuat sistem presidensial, sehingga diperlukannya ambang batas (presidential threshold) bagi partai politik yang mengusulkan pasangan calon Presiden dan Wakil Presiden.

Putusan Mahkamah Konstitusi yang tidak menguji Pasal 9, menimbulkan tafsiran bahwa ambang batas (presidential threshold) tidak perlu lagi atau tidak relevan dan ambang batas (presidential threshold) masih diperlukan, sehingga Mahkamah Konstitusi beranggapan bahwa pembentuk undang-undanglah yang menentukan apakah diperlukan atau tidak ambang batas (presidential threshold) untuk pemilu Presiden dan Wakil Presiden 2019. Pada saat merumuskan UUD 1945 yaitu amandemen UUD 1945, tidak ada ketentuan

10 Putusan Mahkamah Konstitusi Nomor 14/PUU-XI/2013 tentang Uji Materi Undang-Undang Nomor 42 Tahun 2008 tentang Pemilu Presiden dan Wakil Presiden terhdap UUD 1945. 
pasti tentang ambang batas (presidential threshold), sehingga pada saat itu rumusan yang kemudian disepakati adalah mendelegasikan kepada lembaga legislatif untuk mengaturnya dalam Undang-Undang. Apabila pembentuk Undang-Undang menginginkan pemilu legislatif dan pemilu presiden dan wakil presiden dilaksanakan serentak, maka ambang batas (presidential threshold) tetap dapat diterapkan. Sebaliknya apabila ambang batas (presidential threshold) tersebut juga dapat dihilangkan bila Presiden dan DPR sebagai lembaga politik menghendakinya. Pelimpahan kewenangan secara delegatif kepada pembentuk undangundang (baik pemerintah maupun DPR) untuk mengatur tata cara pelaksanaan pemilu Presiden dan Wakil Presiden. Ketentuan lebih lanjut mengenai pemilihan umum serentak memang perlu dilaksanakan karena terdapat hal-hal yang tidak dapat dirumuskan secara langsung dalam UUD 1945 karena sifatnya mudah untuk berubah dan sangat teknis.

Persoalan inilah yang kemudian menjadi pemikiran para pembentuk undang-undang (baik pemerintah maupun DPR) agar sistem presidensial yang dianut dalam UUD 1945 dalam pelaksanaannya menjadi kuat.

\section{Presidential Threshold dan Pemilu Serentak Dalam Penguatan Sistem Presidensial}

Pemilu serentak memang tidak saja berpeluang meletakkan pada jalur pemilu yang terpadu yang dapat menekankan penggunaan anggaran yang besar dari APBN maupun APBD, tetapi juga masalah dengan sistem pemilu yang harus digunakan agar pemilu benarbenar berkualitas dengan menghasilkan sistem pemerintahan yang kuat. Pemilu dilakukan serentak dalam upaya mewujudkan mekanisme demokrasi yang ideal, sehingga ide ini bisa menjadi awal pemikiran akan pemilu yang integratif yang menghasilkan wakil rakyat dan pemerintahan yang terpadu sebagaimana dikehendaki dalam UUD 1945.

Melalui pemilu serentak sesuai dengan UUD 1945, bahwa antara pemilu legislatif dan pemilu Presiden dan Wakil Presiden secara bersamaan dengan meniadakan ambang batas (presidential threshold) merupakan keniscayaan, agar amanat UUD 1945 terlaksana. Oleh karena itu, maka pihak yang mengajukan pasangan calon Presiden dan Wakil Presiden adalah partai politik atau gabungan partai politik peserta pemilu sebelum pelaksanaan pemilu. Di sini Pasal 6A ayat (2) UUD 1945 yang apabila tidak ditafsirkan lain, maka pemberlakuannya tanpa ada hambatan. Sesuai dengan Pasal 6A ayat (2) UUD 1945 dengan pemilu serentak, maka setiap partai politik peserta pemilihan umum dapat mengajukan pasangan calon Presiden dan/ atau Wakil Presiden tanpa syarat mempunyai sejumlah kursi tertentu di DPR. Akan tetapi, sebagaimana dikemukakan di atas, bahwa masalah ambang batas (presidential threshold) dikembalikan lagi kepada pembentuk undangundang. Apabila pembentuk undang-undang mengakali agar ada pembatasan bagi partai politik atau gabungan partai politik dalam mengajukan pasangan calon Presiden dan Wakil Presiden. Berarti menafsirkan Pasal 6A ayat (2) UUD 1945 menjadi lain yaitu dengan pembatasan atau persyaratan tertentu dalam mengajukan pasangan calon Presiden dan calon Wakil Presiden.

Sebenarnya dalam Pasal 6A UUD 1945 tidak menentukan adanya ambang batas (presidential threshold) dalam Pemilu Presiden dan Wakil Presiden, yang ada hanyalah "pasangan calon Presiden dan calon Wakil Presiden diajukan 
oleh partai politik atau gabungan partai politik peserta pemilihan umum". Asumsi bahwa apabila sebuah partai politik secara hukum menjadi peserta pemilu berarti berhak mengajukan pasangan Calon Presiden dan calon Wakil Presiden tanpa harus ada syarat ambang batas (presidential threshold).

Ada yang berpendapat, apabila pemilu legislatif bersamaan dengan pemilu presiden dan wakil presiden dengan meniadakan ambang batas (presidential threshold), maka salah satu kelemahan adalah kemungkinan terpilihnya figur Presiden dari partai kecil (partai gurem) yang memiliki sedikit atau bahkan tidak mempunyai sama sekali wakil di DPR. Figur Presiden ini yang kemudian terpilih akan sulit mendapat dukungan politik di parlemen sehingga tidak akan efektif dan stabilitas pemerintahan yang tidak baik. Kekhawatiran tersebut kemudian mendorong pembentuk undang-undang agar tetap mengatur ambang batas (presidential threshold), bahkan ambang batas (presidential threshold) harus tinggi, karena pemilu serentak otomatis menghilangkan ambang batas (presidential threshold).

Selanjutnya apabila ambang batas (presidential threshold) tetap diberlakukan, maka akan meningkatkan kualitas calon Presiden dan Wakil Presiden karena melalui proses seleksi yang dilakukan oleh partai politik. Di samping itu, penghapusan ambang batas (presidential threshold) akan berdampak pada kepemimpinan eksekutif yang tidak akan mendapatkan dukungan dari parlemen, sehingga akan sulit untuk melaksanakan kebijakan. Pemerintah dan DPR sebagai pembentuk Undang-Undang dapat saja memberlakukan ambang batas (presidential threshold) pada pemilu 2019, asalkan aturan ambang batas (presidential thresho/d) disesuaikan dengan kursi di DPR pada pemilu legislatif 2014 ini. Sebenarnya ada sisi positifnya apabila ambang batas (presidential threshold) tetap diberlakukan di antaranya:

1. Apabila ambang batas (presidential threshold) ditiadakan, parlemen cenderung dominan sehingga memperlemah sistem presidensial.

2. Apabila ambang batas (presidential threshold) tetap tinggi memaksa partai politik atau gabungan partai politik memperkuat sistem presidensial dan akan menyeleksi calon Presiden dan Wakil Presiden.

3. Akan terjadi koalisi untuk memperkuat pelaksanaan pemerintahan, sehingga akan membangun pemerintahan yang efektif.

4. Ambang batas (presidential threshold) dalam pengajuan calon Presiden dan calon Wakil Presiden dimaksudkan untuk menyederhanakan sistem kepartaian.

Melihat kenyataan demikian, menjadi calon Presiden dan Wakil Presiden tidaklah mudah, karena harus memenuhi persyaratanpersyaratan tertentu yang diatur dalam UndangUndang Nomor 42 Tahun 2008. Calon Presiden tidak hanya diusulkan oleh partai politik atau gabungan partai politik, juga partai politik atau gabungan partai politik harus memenuhi ambang batas (presidential threshold) yaitu partai politik atau gabungan partai politik harus memenuhi perolehan kursi paling sedikit 20\% (dua puluh persen) dari jumlah kursi di DPR atau memperoleh $25 \%$ (dua puluh lima persen) dari suara sah nasional dalam pemilu anggota DPR. Dengan demikian, dengan mengkaji permohonan uji materi Undang-Undang Nomor 42 Tahun 2008 terhadap UUD 1945 yang diajukan oleh Yusril Ihza Mahendra, yaitu tidak hanya pemilu serentak antara pemilu legislatif dengan pemilu presiden dan wakil 
presiden saja, tetapi juga mengenai peniadaan atau dihapuskannya ambang batas (presidential threshold) dalam pemilu presiden dan wakil presiden. Refly Harun sebagaimana dinyatakan dalam diskusi mingguan, bahwa syarat ambang batas pengajuan calon presiden atau presidential threshold (PT) yang diatur dalam Undang-Undang Nomor 42 Tahun 2008 tentang Pemilihan Presiden tidak didasari argumentasi yang tepat. Penerapan PT untuk mengusung pasangan calon presiden dan wakil presiden dianggapnya sebagai permainan politik partaipartai besar, penerapan PT dalam UndangUndang Pilpres tidak masuk akal, karena UUD 1945 telah mengatur bahwa presiden terpilih berdasarkan perolehan suara $50 \%$ plus satu dan tersebar di $20 \%$ provinsi. Selanjutnya, pernyataan yang menyatakan bahwa penerapan PT dilakukan untuk memperkuat sistem presidensial juga tidak bisa dibuktikan. Apabila Presiden yang terpilih berasal dari partai kecil, pembentukan kabinet juga pasti akan dilakukan secara koalisi. Contoh lainnya adalah Partai Demokrat dengan suara minoritas pada tahun 2009 akhirnya mengajak partai Golkar masuk dalam kabinet meski dalam pemilihan presiden harus berkompetisi. ${ }^{11}$

Argumen bahwa pemilu serentak dengan meniadakan ambang batas (presidential threshold) akan memperlemah sistem presidensial tidaklah tepat karena kenyataannya selama Presiden Susilo Bambang Yudhoyono (SBY) pada periode kedua berjalan sejak tahun 2009 pemerintahan juga tidak didukung oleh sepenuhnya partai pendukung, bahkan partai pendukungnya yang selalu menghambat kebijakan yang dijalankan oleh Presiden. Hal ini justru sebaliknya, partai politik di DPR yang tidak masuk dalam koalisi yang kelihatannya mendukung kebijakan yang dijalankan oleh Presiden. Selain itu, terdapat juga tarik menarik kepentingan antara Presiden dengan partai pendukung dalam penentuan susunan kabinet. Presiden SBY kelihatan tersandera harus menentukan pembantunya berdasarkan komposisi jatah kursi bagi partai pendukungnya, sehingga Presiden SBY tidak lagi memiliki kontrol penuh terhadap para menterinya.

Argumen ambang batas (presidential threshold) untuk memperkuat sistem presidensial, efektifnya pemerintahan oleh Presiden terpilih, penyederhanaan kepartaian dan menyeleksi calon Presiden dan Wakil Presiden tidak sepenuhnya tepat. Hal ini karena partai politik sebagai peserta pemilu sudah diseleksi secara ketat oleh KPU, sehingga partai politik yang lolos verifikasi yang ketat sebagai partai politik peserta pemilu yang kemudian mengusulkan calon Presiden dan Wakil Presiden. Penyeleksian partai politik peserta pemilu yang dilakukan oleh KPU sebagai bentuk penyederhanaan sistem kepartaian.

Pembentuk Undang-Undang (Pemerintah dan DPR) harus memikirkan ulang tentang ambang batas (presidential threshold) yang terdapat dalam Pasal 9 Undang-Undang Nomor 42 Tahun 2008 yaitu 20\% (dua puluh persen) dari jumlah kursi DPR atau memperoleh 25\% (dua puluh lima persen) dari suara sah nasional dalam pemilu anggota DPR, karena akan membatasi rakyat untuk mendapatkan alternatif pilihan yang lebih banyak dan juga lebih baik. Pembatasan calon berarti membatasi saluran politik warga negara sebagai pemilih

\footnotetext{
11 http://nasional.kompas.com/read/, (diakses tanggal 10 Maret 2014).
} 
yang kemudian tidak mustahil akan membentuk masyarakat golput, karena calon mereka yang akan dipilih dari pasangan calon Presiden dan Wakil Presiden tidak ada. Penghapusan ambang batas (presidential threshold) juga meningkatkan partisipasi warga negara sebagai pemilih karena daya tarik calon Presiden dan Wakil Presiden lebih banyak pilihannya.

Sistem presidensial yang dianut UUD 1945 merupakan sistem presidensial murni, sehingga presiden tidak dapat dijatuhkan begitu saja oleh partai politik yang duduk di parlemen, meskipun partai politik itu mempunyai kursi mayoritas di DPR. Menurut Syamsuddin Harris, secara teoritis basis legitimasi seorang presiden dalam skema sistem presidensial tidak ditentukan oleh formasi politik parlemen hasil pemilu legislatif. Lembaga presiden dan parlemen dalam sistem presidensial adalah dua intitusi terpisah yang memiliki basis legitimasi berbeda. ${ }^{12}$ Dengan demikian, sistem presidensial akan tetap efektif dan kuat dalam pemerintahan, meskipun pemilu serentak dilaksanakan tanpa harus ada persyaratan tertentu seperti ambang batas (presidential threshold) bagi partai politik pengusung calon Presiden dan Wakil Presiden. Undang-Undang Dasar 1945 itu sendiri yang menyatakan bahwa sistem presidensial yang dianutnya berbeda dengan negara-negara lain yang mempunyai posisi yang kuat seorang Presiden dalam menjalankan pemerintahannya.

Sistem presidensial memperoleh posisi kuat sesuai dengan UUD 1945, karena pemerintahan presidensial di Indonesia antara lain: Presiden memegang kekuasaan Pemerintahan menurut
Undang-Undang Dasar (Pasal 4 ayat (1) UUD 1945), Presiden dan wakil presiden dipilih oleh rakyat secara langsung (Pasal 6A ayat (1) UUD 1945), Masa jabatannya tertentu (Pasal 7 UUD 1945), Presiden dan Wakil Presiden tidak bertanggung jawab kepada parlemen (melainkan langsung bertanggung jawab kepada rakyat sebagai pemilihnya), menterimenteri diangkat, bertanggung jawab dan diberhentikan oleh Presiden, begitu juga dalam hubungannya dengan parlemen, presiden tidak tunduk kepada parlemen, dan tidak dikenal adanya perbedaan antara fungsi kepala negara dan kepala pemerintahan.

Menurut Moh. Mahfud M.D., bahwa eksekutif dan legislatif sama-sama kuat, sering disalahmaknakan menjadi suatu kebutuhan nyata bahwa Presiden dan Wakil Presiden dalam Sistem Presidensial, bahkan sebelum dia dipilih langsung oleh rakyat sudah membutuhkan basis dukungan dari Dewan Perwakilan Rakyat dalam rangka mewujudkan efektivitas pemerintahan. ${ }^{13}$ Penelitian berkelanjutan Ilmuwan Komunikasi Politik dan Politik makin menemukan bahwa dalam sistem presidensial, presiden dan wakil presiden terutama harus mengutamakan kepentingan warga negara yang memilihnya secara langsung, tentu akan sangat baik jika kepentingan akumulasi anggota parlemen mendukung Program dan Tindakan Presiden yang mengutamakan kepentingan warga negara. ${ }^{14}$ Argumen tersebut memperkuat bahwa sisten presidensial yang dianut UUD 1945 tidak terpengaruh oleh adanya pemilu 
serentak baik dengan penerapan ambang batas (presidential threshold) atau pun tidak.

\section{E. Penutup}

Pembentuk Undang-Undang (baik pemerintah maupun DPR) untuk memikirkan kembali pengaturan ambang batas (presidential threshold) dalam pemilihan umum presiden dan wakil presiden yang bersamaan dengan pemilu legislatif. Pengaturan ambang batas (presidential threshold) perlu ditinjau kembali dalam merumuskan kembali Undang-Undang tentang Pemilihan Umum Presiden dan Wakil Presiden, sehinggaa tidak bertentangan dengan amanat konstitusi yaitu UUD 1945 terutama Pasal 6 dan Pasal 6A UUD 1945. Hal ini apabila pengaturan ambang batas (presidential threshold) untuk pemilu presiden diberlakukan juga tidak akan mempengaruhi sistem pemerintahan presidensial, karena UUD 1945 sudah mengatur sedemikian dan mendesain bahwa kedudukan presiden sama dengan lembaga negara lain dan tidak saling menjatuhkan serta presiden dalam menjalankan pemerintahannya menurut Undang-Undang Dasar. Ambang batas (presidential threshold) dalam pemilu presiden yang bersamaan dengan pemilu legislatif sebaiknya ditiadakan saja, karena hak warga negara untuk menentukan pilihan sesuai dengan hati nuraninya dan agar alternatif pilihan presiden dan wakil presiden lebih banyak, sehingga dapat menentukan mana calon yang berkualitas atau tidak.

\section{DAFTAR PUSTAKA}

\section{Buku}

Alrasyid, Harun, Pengisian Jabatan Presiden (Jakarta: Pustaka Utama Grafiti, 1999).

Alrasyid, Harun, Pemilihan Presiden dan Pergantian Presiden Dalam Hukum Positif Indonesia, (Jakarta: YLBHI, 1997).

Asshiddiqie, Jimly, Hukum Tata Negara dan PilarPilar Demokrasi (Jakarta: Sinar Grafika, 2011).

Indrayana, Deny, Amandemen UUD 1945, antara Mitos dan Pembongkaran (Jakarta: Mizan Pustaka, 2008).

Kusnardi, Moh. dan Harmaily Ibrahim, Pengantar Hukum Tata Negara Indonesia (Jakarta: Pusat Studi HTN FH UI, 1983).

Lilphart, Arend (Penyadur: Ibrahim dkk), Sistem Pemerintahan Parlementer dan Presidensial (Jakarta: Raja Grafindo Persada, 1995).

Tutik, Titik Triwulan, Konstruksi Hukum Tata Negara Indonesia Pasca Amandemen UUD 1945, (Jakarta: Prenada Media Group, 2010).

\section{Makalah / Artikel / Prosiding / Hasil Penelitian}

Syamsuddin Haris, "Salah Kaprah "Presidential Threshold" dalam Harian SINDO, 30 Oktober 2012.

Soemantri, Sri, "Kekuasaan dan Sistem Pertanggungjawaban Presiden Pasca Perubahan UUD 1945" (Makalah Seminar Sistem Pemerintahan Indonesia Pasca Amandemen UUD 1945 yang diselenggarakan oleh Depkumham bekerja sama dengan Fakultas Hukum Unair dan Kanwil Depkumham Provinsi Jawa Timur di Surabaya pada tanggal 9-10 Juni 2004).

\section{Internet}

http://nasional.kompas.com/read/, (diakses 10 Maret 2014).

\section{Putusan Pengadilan}

Putusan Mahkamah Konstitusi Nomor 14/PUU$\mathrm{XI} / 2013$ tentang Uji Materi Undang-Undang Nomor 42 Tahun 2008 tentang Pemilu Presiden dan Wakil Presiden terhdap UUD 1945. 